\title{
5
}

\section{The Guardian of the Regime: the Turkish Constitutional Court in Comparative Perspective}

\author{
HOOTAN SHAMBAYATI
}

$\mathrm{M}$

ANY MODERN CONSTITUTIONS, including those included in this volume, reflect ambitious programmes for transforming existing social, economic and political interests through political engineering. In countries like Iran and Turkey the underlying ideal of the constitution is not the protection of the existing nation but nothing less than the creation of a new nation. As Arjomand has noted, this desire for social engineering through constitutionalism is a characteristic of ideological constitutions found in many developing countries. ${ }^{1}$

The attempt to transform the nation, however, is often at the expense of powerful actors and is opposed by significant portions of the society. As a result the state emerges as an 'enlightened' institution whose job is not only designing a system that will bring the 'nation to the level of contemporary civilization'2 but also a system that will protect the civilizing project against its 'enemies', even when those enemies are a majority in the polity. The Islamic revolution of 1979 in Iran adopted this project by proposing a new order of a different kind. For Turkish leaders, 'contemporary civilization' is Western and secular. For their Iranian counterparts, it is Islamic and theocratic. For both, the mission is the transformation of the nation.

In this chapter, I argue that the civilizing mission of the state in Turkey has led to the creation of a regime with guardians where elected and unelected institutions jointly exercise power. The presence of guardians requires the creation of institutions such as constitutional courts that serve to preserve

1 SA Arjomand, 'Law, Political Reconstruction and Constitutional Politics' (2003) 18 International Sociology (March) 7-32.

2 This oft-repeated phrase is from a speech delivered by Ataturk on the Occasion of the Tenth Anniversary of the Foundation of the Turkish Republic, 29 October 1933, available at www.allaboutturkey.com/ata_speech.htm 
the above politics posture of the guardians by putting a distance between them and day-to-day politics. What distinguishes these institutions from their counterparts in consolidated democracies is that despite their political importance they are isolated from elected institutions and their primary role is to protect the ideological dominance of the guardians.

The case of Turkey is, however, by no means unique, and extra-political institutions are a characteristic of many regimes with guardians. As Haggard and Kaufman have argued, regimes with guardians create 'insulated decisionmaking structures that can be counted on to pursue [the guardian's] policy agenda' ${ }^{3}$ without relying on elected institutions. To demonstrate this, I will offer a brief discussion of the Iranian system and the role of that country's Guardian Council. In Iran, the division of sovereignty between an elected parliament and president representing the will of the people and the Supreme Leader representing the alleged will of God has created a political system that relies heavily on extra-political institutions. My comparison highlights the similarity of the two political systems with guardians despite their diametrically opposite ideologies.

\section{THE TURKISH CONSTITUTION: DEMOCRATIC DEFICIT}

In 1945, Turkey abandoned the single-party system that had been in place since the establishment of the Republic two decades earlier. Five years later, the opposition Democrat Party (DP) won an overwhelming majority in parliamentary elections and replaced the Republican People's Party (RPP) as the governing party. Turkey's first experience with democracy came to an end in May 1960 when the military overthrew the DP government. The return to civilian government and multiparty politics was swift, but before leaving office in 1962, the military government put in place a new constitution which governed Turkey for the next two decades and in some surprising ways established the basis for the post-1982 constitutional system. Although many students of Turkish politics agree that the 1982 Constitution is illiberal in nature and imposes severe restrictions on rights and liberties, they tend to view the 1961 Constitution as liberal. As the discussion below suggests, however, many of the restrictive institutions of the 1982 Constitution have their roots in the 1961 document.

As Ergun Özbudun notes, the 1961 Constitution 'reflected the basic political values and interests of the state elites'. ${ }^{4}$ Believing that the DP governments had abused governmental power, the framers of the new constitution

3 S Haggard and RR Kaufman, The Political Economy of Democratic Transitions (Princeton, Princeton University Press, 1995) 121.

4 E Özbudun, Contemporary Turkish Politics: Challenges to Democratic Consolidation (Boulder, Rienner, 2000) 54. 
tried to divide sovereignty and the exercise of political power among various institutions. Accordingly, Article 4 of the 1961 Constitution read:

Sovereignty is vested in the nation without reservation and condition. The nation should exercise its sovereignty through the authorised agencies as prescribed by the principles laid down in the Constitution.

The official webpage of the Turkish Constitutional Court interprets the second sentence as 'putting an end to the principle of the supremacy of Parliament'. ${ }^{5}$ This concept is also present in the 1982 Constitution, where the exact wording of its 1961 predecessor is repeated in Article 6. As the webpage continues, 'With the adoption of this new principle the Turkish Grand National Assembly ceased to be the sole organ empowered to exercise sovereignty on behalf of the nation'. ${ }^{6}$ The result has been the creation of a bifurcated political system based on the division of sovereignty between elected institutions and unelected guardians.

The Turkish political system is a hybrid of electoral democracy and authoritarian tendencies, where elected institutions share the exercise of sovereignty with non-elected and democratically unaccountable actors. This dichotomy has resulted in a sharp distinction between what the Turkish public identifies as the state (devlet), composed of the military, security agencies and the judiciary, and the government (bükümet), composed of the parliament and the cabinet.

To put into operation the division of sovereignty, the 1961 Constitution created a number of institutions that were further strengthened under the 1982 Constitution. Most important among these institutions are the National Security Council and the Constitutional Court. In addition, a number of other 'illiberal' institutions like the State Security Courts and the Council of Higher Education were first introduced in the 1970s and achieved constitutional status in 1982.

Originally thought of as a forum for the exchange of views between civilian institutions and the military establishment, the role of the National Security Council (NSC) was strengthened in the 1970s and then again by the 1982 Constitution. Article 118 of the 1982 Constitution enumerates the membership and the duties of the NSC. In its original version, which remained in effect until 2001, it read:

The National Security Council shall be composed of the Prime Minister, the Chief of the General Staff, the Ministers of National Defense, Internal Affairs, and Foreign Affairs, the Commanders of the Army, Navy, and the Air Force, and the General Commander of the Gendarmerie, under the chairmanship of the President of the Republic.

\footnotetext{
5 See www.anayasa.gov.tr/engconst/COURT.HTM

6 Ibid.
} 


\section{2}

Depending on the particulars of the agenda, Ministers and other persons concerned may be invited to meetings of the Council and their views be heard.

The National Security Council shall submit to the Council of Ministers its views on taking decisions and ensuring necessary coordination with regard to the formulation, establishment, and implementation of the national security policy of the State. The Council of Ministers shall give priority consideration to the decisions of the National Security Council concerning the measures that it deems necessary for the preservation of the existence and independence of the State, the integrity and indivisibility of the country, and the peace and security of society. (emphasis added)

While the 'decisions' of the NSC are theoretically only advisory, and the final decision for their implementation is left to the council of ministers and the parliament, it is clear that the framers of the constitution conceived of the NSC as an important actor in the decision-making process. ${ }^{7}$

Over the years the council has used a very inclusive definition of security and has discussed all kinds of issues concerning domestic and foreign policy. At times, this has resulted in major confrontations between the civilian governments and the military-wing of the NSC. In 1997, for example, the military forced the resignation of the government led by the Islamist Refah party, even though the party was the largest single party in the parliament. It is also worthy to note that the economic crisis of 2001, which resulted in the rapid devaluation of the Turkish currency, was triggered by a confrontation between the President and the Prime Minister during an NSC meeting.

Although the role of the military in Turkish politics has been extensively studied and has been the subject of much discussion, the NSC is not the only constitutional institution that shares in the exercise of sovereignty. As Pereira notes, 'military strength and autonomy cannot be achieved by the military alone but must be nurtured and sustained by legal and legislative projects that convert parts of the judiciary and the congress into defenders of the status-quo'. ${ }^{8}$ An equally important, but much less commented upon institution, is the Constitutional Court.

\section{THE CONSTITUTIONAL COURT AND THE JUDICIALISATION OF TURKISH POLITICS}

When sovereignty is divided between elected and non-elected institutions, conditions are ripe for judicialisation of politics, or the expansion of the

\footnotetext{
7 In preparation for Turkey's eventual entry into the European Union the parliament has adopted a number of constitutional amendments with the aim of reducing the military's role in politics. Accordingly, in 2001 the composition of the NSC was changed to increase the number of civilian members and to emphasise the council's advisory role. In addition, a civilian replaced the council's military Secretary-General.

8 AW Pereira, 'Virtual Legality: Authoritarian Legacies and the Reform of Military Justice in Brazil, the Southern Cone, and Mexico' (2001) 34(5) Comparative Political Studies (June) 557.
} 
judiciary's role in the political arena. ${ }^{9}$ The adoption of a system based on divided sovereignty signifies a schism in the ruling coalition concerning the nature of sovereignty. Judicialisation of the political arena can be an attractive way for constitutional drafters to deal with this problem. As Hirschl has noted, the political empowerment of the courts is a form of 'hegemonic preservation', where a political elite that is losing its dominance tries to protect its values and interests by empowering a sympathetic judiciary. ${ }^{10}$ Although Hirschl does not apply his model to transitions from military rule, this scenario seems to be particularly likely in such transitions. Whereas civilian authoritarians can regroup in the post-transition era and compete in democratic elections, that route is not available to military regimes. An outgoing military regime must ensure the continued protection of its institutional interests before leaving office.

Although national security councils, or similar institutions, can go a long way in meeting this goal, they also run the danger of undermining the abovepolitics posture of the military-as-institution. As one of the legal advisors to the Chilean military junta and one of the primary authors of the that country's 1980 Constitution noted, 'everyone is in agreement not to develop a formula that, in fact, implies the politicization of the armed forces, since it is evident that if one seeks to preserve an institution's character as permanent safeguard one should take precaution not to waste it upon the contingent'. ${ }^{11}$ As the Turkish experience shows, in transitions from military rule, the empowerment of the judiciary is a mechanism to minimise the need for direct participation of the military in day-to-day politics while at the same time protecting the outgoing regime's interest under civilian rule. Military regimes might have strong incentives to adopt judicial review as an 'insurance policy'. ${ }^{12}$

\section{THE TURKISH CONSTITUTIONAL COURT: INSTITUTIONAL DESIGN}

What distinguishes the post-1982 Turkish Constitutional Court from its European counterparts is its 'apolitical' appointments procedure and its eagerness to override the parliament. ${ }^{13}$ Between 1982 and 2000, the Court

${ }^{9}$ H Shambayati, 'A Tale of Two Mayors: Courts and Politics in Turkey and Iran' (2004) International Journal of Middle East Studies (May) 253-75.

${ }_{10} \mathrm{R}$ Hirschl, Towards Juristocracy: the Origins and Consequences of the New Constitutionalism (Cambridge, MA, Harvard University Press, 2004).

${ }^{11}$ Cited in R Barros, Constitutionalism and Dictatorship: Pinochet, the Junta, and the 1980 Constitution, Cambridge Studies in the Theory of Democracy (Cambridge, Cambridge University Press, 2002) 244.

12 As Ginsburg notes, 'by serving as an alternative forum to challenge government action, judicial review provides a form of insurance to prospective electoral losers during the constitutional bargain'. T Ginsburg, Judicial Review in New Democracies: Constitutional Courts in Asian Cases (Cambridge, Cambridge University Press, 2003) 25.

13 There are very few scholarly studies devoted to the Turkish Constitutional Court. Among the more important ones are Z Arslan, 'Conflicting Paradigms: Political Rights in the Turkish 
annulled 72 per cent of the cases it received for abstract review. In addition, since 1983 it has closed 18 political parties, including three political parties with representation in the parliament. At the same time, since 1982 the parliament has had no role in appointments to the Court.

The Court began operations in 1962 with 15 permanent members appointed by the bicameral parliament (three Grand National Assembly, two Senate), the high courts, and the President of the Republic. Like its counterpart in other countries, the military regime that came to power in September 1980 did not openly interfere with the Constitutional Court, although it did appoint some new members to the Court. ${ }^{14}$ The military regime, however, suspended the constitution and exempted its own decisions from review by the Court.

The framers of the 1982 Constitution reduced the number of justices to 11 regular and four substitute members. Most importantly, they eliminated the five justices appointed by the parliament and increased the number of justices nominated by the military courts from one to two. The President of the Republic, a 'nonpartisan' official elected by the unicameral parliament, ${ }^{15}$ appoints all justices of the Constitutional Court from among candidates nominated by other high courts and the Higher Education Council. ${ }^{16}$ Seven out of the 11 seats on the Court are reserved for the judiciary. The president also appoints one justice from among the teaching staff of the universities nominated by the Higher Education Council and three justices from among high civil servants and lawyers. It is not unusual for some of these appointees to be retired military judges. Justices of the Constitutional Court have to be at least 40 years old at the time of their appointment and retire at age 65. This apolitical appointment procedure of the Turkish Constitutional Court betrays the framers distrust of politicians and political institutions. Under the 1982 Constitution, and in sharp contrast with other Western democracies, the parliament has no role in appointments to the Constitutional Court. ${ }^{17}$

Constitutional Court' (2002) 11 Critique: Critical Middle Eastern Studies (Spring) 9-25; D Kogacioglu, 'Dissolution of Political Parties by the Constitutional Court in Turkey: Judicial Delimitation of the Political Domain' (2003) 18 International Sociology (March) 258-76; D Kogacioglu, 'Progress, Unity, and Democracy: Dissolving Political Parties in Turkey' (2004) 38(3) Law and Society Review 433-62.

${ }^{14}$ For other examples, see CN Tate, 'Courts and Crisis Regimes: a Theory Sketch with Asian Case Studies' (1992) Political Research Quarterly 311-38; see also R Barros, Constitutionalism and Dictatorship: Pinochet, the Junta, and the 1980 Constitution (Cambridge, Cambridge University Press, 2002); JC Sutil, 'The Judiciary and the Political System in Chile: the Dilemmas of Judicial Independence during the Transition to Democracy' in I Stotzky (ed), Transition to Democracy in Latin America: the Role of the Judiciary (Boulder, Westview, 1993).

15 The 1982 Constitution abolished the Senate.

16 This controversial body was established after the 1980 coup and has the duty of supervising institutions of higher education. Its members are appointed by the President of the Republic and include a nominee of the chief of staff of the military.

17 The change in the judicial appointment procedures was part of an overall attempt to augment the powers of the presidency. The framers of the 1982 Constitution conceived of the presidency as a watchdog over the popularly elected institutions. They also hoped that by 
Another distinguishing feature of the Turkish Constitutional Court is the role of the military in appointments to the Court. Two justices of the Constitutional Court are appointed from among members of the High Military Administrative Court (Askeri Yüksek Idare Mahkemesi) and the Military Court of Cassation (Askeri Yargitay) based on nominations by the plenary session of the two institutions. Although these justices resign their military commission before assuming their seat on the Constitutional Court, they are products of the military's justice system and the manner of their nomination can provide the military with a mechanism to influence the composition of the Court. ${ }^{18}$ Technically, the military could also influence the nomination of the candidates put forward by the Higher Education Council, a controversial body established after the 1980 coup to supervise civilian (but not military) institutions of higher education. Until 2004 a representative of the Chief of Staff sat on the Council's governing board.

Both Dicle Kogacioglu and Nathan Brown see some virtue in apolitical judicial appointment procedures. Kogacioglu has argued that the appointment procedure of the Turkish Constitutional Court has enhanced the legitimacy of the Court in the public's eye. ${ }^{19}$ Similarly Brown, using the example of Egypt's Supreme Constitutional Council, advocates isolating the courts from the Arab executives and legislatures in order to enhance judicial independence and increase the possibility of the courts standing up to the other branches. He is, however, quick to add that none of the Arab countries are democracies. ${ }^{20}$

Isolating the judiciary from executives and legislatures might be desirable if those branches themselves are not democratic. In democracies, on the other hand, a partially politicised appointment procedure is not only necessary for establishing democratic legitimacy of judicial review but also for producing more democratic results. Deepening democracy and preservation of judicial independence require measures to reduce the dangers of ideological uniformity on the bench. As Russell has noted, 'to guard against

augmenting the powers of the President they would allow for the continued participation of the military in policy-making after the transition to civilian rule. A provisional article of the constitution declared that General Evren, the leader of the 12 September 1980 military coup and one of the main authors of the constitution, would become President of the Republic upon the ratification of the constitution. Furthermore, the framers hoped that the pre-coup tradition of electing recently retired military commanders to the presidency would continue after the transition to civilian rule. Until the election of Turgut Ozal as President in 1989, Celal Bayar (1950-1960) had been Turkey's only civilian President.

18 The role of the military in appointments to the Constitutional Court is to some extent reminiscent of the role of the Chilean military in appointing two out of seven members of that country's Constitutional Tribunal under the 1980 Constitution. In that country, however, the Constitutional Tribunal has more limited political functions.

${ }^{19}$ D Kogacioglu, 'Progress, Unity, and Democracy: Dissolving Political Parties in Turkey', above $\mathrm{n} 13$, at $441 \mathrm{n} 22$.

${ }^{20}$ NJ Brown, Constitutions in a Non-Constitutional World (Albany, State University of New York, 2002) 150-2 and 159. 
a politically unbalanced judiciary, liberal democracies are well advised to build social and political pluralism into their judicial appointing arrangements'. 21

The apolitical appointment procedure of the Turkish Constitutional Court has produced a remarkably homogeneous court where not only most members are jurists but they also have had very similar educational backgrounds and life experiences. As a consequence, although the Court has emerged as a powerful political actor and has not shied away from confronting the parliament, it has been more cautious in dealing with the state.

\section{Acting like a Senate}

The Turkish Constitutional Court sees its primary role as 'counterbalanc[ing] political institutions and especially Parliament in order to avoid an abuse of powers'. ${ }^{22}$ To make this possible, the 1961 Constitution adopted a very liberal definition of standing and authorised the President of the Republic, political parties represented in the parliament, one-sixth of the members of each house of the legislature, ${ }^{23}$ and any political party which had mustered at least 10 per cent of the votes in the last national election, to petition the Constitutional Court for abstract review. In addition, the plenary sessions of the high courts and the universities were allowed to petition the Court 'in cases concerning their duties and welfare' (Article 149). This liberal definition of standing meant that in the polarised political environment of the 1960s and the 1970s, a large number of laws and regulations were referred to the Court. ${ }^{24}$ Between 1962 and the September 1980 military coup, the Constitutional Court received an average of 19 cases per annum for abstract review. It found grounds for unconstitutionality in 37 per cent of these cases.

The involvement of the court in the political arena encouraged further polarisation of the political life and opened the court to charges by

${ }^{21}$ PH Russell, 'Toward a General Theory of Judicial Independence' in PH Russell and DM O'Brien (eds), Judicial Independence in the Age of Democracy (Charlottesville, University Press of Virginia, 2001) 17. See also chapters by Guarnieri, Kommers and Corder in the same volume.

${ }^{22}$ See www.anayasa.gov.tr/engconst/COURT.HTM

23 The 1961 Constitution created a senate to reduce the powers of the lower house, the Grand National Assembly. The senate was abolished by the 1982 Constitution.

24 Turning to the courts at times of political crisis is not unique to Turkey. For examples from other countries see J Linz, The Breakdown of Democratic Regimes: Crisis, Breakdown, and Reequilibrium (Baltimore, Johns Hopkins University Press, 1978); CN Tate, 'Courts and the Breakdown and Recreation of Philippine Democracy: Evidence from the Supreme Court's Agenda' (1997) International Social Science Journal (Special Issue: Democracy and Law) 279; A Valenzuela, The Breakdown of Democratic Regimes: Chile (Baltimore, Johns Hopkins University Press, 1978). 
politicians that the Constitutional Court was usurping the powers of the parliament and was making it impossible for the government to function properly. ${ }^{25}$ As Dodd notes:

the Constitutional Court and the Council of State, manned by the most enlightened of those who represented the tradition of the Ataturkist state, might well have been able to establish a rapport with a stable majority government. In conditions of unstable government and intense political rivalry it was difficult for these institutions not to be seen to be engaged in the political struggle. ${ }^{26}$

Between its establishment in 1962 and the military coup of 1980, the Court was occasionally willing to annul some of the more restrictive legislation favoured by the state. In 1975, for example, the Court struck down most of the provisions of a law that attempted to decrease the autonomy of universities and establish a council to oversee all institutions of higher education. Similarly, a year later the Court ordered the closure of State Security Courts. Both institutions were resurrected after the 1980 coup and were given constitutional status in the 1982 Constitution.

The framers of the 1982 Constitution reacted to the Court's controversial decisions by changing the appointment procedures and the rules of standing. Under the system in place since 1982, the power of referral belongs to the President of the Republic, the parliamentary group of the main party in government, the main opposition party (the largest parliamentary party outside of government), or one-fifth (at present 110) of the members of the unicameral parliament. ${ }^{27}$

Parliamentary deputies and the President submit most petitions for abstract review. In general, however, the President can use his veto power to stop 'unacceptable' legislation. Although overriding a presidential veto is relatively easy, ${ }^{28}$ depending on the relationship between the President and the government, the parliament usually defers to the presidential judgement and amends the provisions in question..$^{29}$ As in other countries with

${ }^{25}$ F Ahmad, Turkish Experiment in Democracy, 1950-1975 (Boulder, Westview, 1977) 245; CH Dodd, Crisis of Turkish Democracy (Huntingdon, UK, Eothen Press,1990) 34.

26 Dodd, above n 25, at 64-5.

27 Abstract review procedures in Turkey are a posteriori. The legislation in question must first be implemented before its constitutionality can be challenged. Institutions with standing have to file their petitions for the annulment of the contested law or decree within 60 days after its publication in the Official Gazette.

${ }^{28}$ If the parliament passes the objectionable provisions without amendment for a second time the legislation becomes law without the President's signature.

29 This was particularly true during the presidency of Turgut Ozal and Suleyman Demirel, two veteran politicians and former prime ministers, who continued to maintain a political base even after assuming the presidency. Turkey's current president, Ahmet Necdet Sezer, however, does not have an organised political base. A career judge who at the time of his appointment to the presidency was the president of the Constitutional Court, Sezer has relied more heavily on the Court. 
Table 5.1: Abstract Review Cases Decided by the Turkish Constitutional Court

\begin{tabular}{lcrrrrr}
\hline Year & Docket & New cases & Annulled $\begin{array}{c}\text { Objection } \\
\text { rejected }\end{array}$ & $\begin{array}{c}\text { Total cases } \\
\text { decided }\end{array}$ & Annulled \\
\hline 1984 & & 6 & 0 & 2 & 2 & 0 \\
1985 & 6 & 12 & 3 & 5 & 8 & 38 \\
1986 & 16 & 10 & 7 & 3 & 10 & 70 \\
1987 & 18 & 13 & 7 & 6 & 13 & 54 \\
1988 & 17 & 10 & 9 & 2 & 11 & 82 \\
1989 & 14 & 8 & 6 & 2 & 8 & 75 \\
1990 & 19 & 13 & 6 & 4 & 10 & 60 \\
1991 & 15 & 7 & 8 & 2 & 10 & 80 \\
1992 & 10 & 5 & 6 & 1 & 7 & 86 \\
1993 & 23 & 20 & 21 & 2 & 23 & 91 \\
1994 & 19 & 19 & 17 & 1 & 18 & 94 \\
1995 & 14 & 13 & 11 & 1 & 12 & 92 \\
1996 & 17 & 16 & 8 & 2 & 10 & 80 \\
1997 & 11 & 4 & 5 & 3 & 8 & 63 \\
1998 & 5 & 2 & 1 & 3 & 4 & 25 \\
1999 & 13 & 12 & 4 & 4 & 8 & 50 \\
2000 & 34 & 29 & 21 & 2 & 23 & 91 \\
Years & Ave. per & New & Annulled & Rejected & Total & \% Annulled \\
& year & & & & & \\
$1962-1980$ & 19 & 350 & 129 & 220 & 349 & 37 \\
$1984-2000$ & 12 & 199 & 140 & 45 & 185 & 76 \\
\hline
\end{tabular}

Source: Turkish Republic, State Institute of Statistics, Judicial Statistics (various years) and Anayasa Mahkemesi.

abstract review, most cases are brought before the Constitutional Court by the parliamentary opposition, a practice that increases the potential for the judicialisation of the political process. ${ }^{30}$ The frequency with which the opposition has used this strategy led one president of the Court to complain that the Constitutional Court had become 'like a senate'. ${ }^{31}$ This, however, has not stopped the Court from using its powers to strike down parliamentary acts and governmental decrees.

As Table 5.1 shows, the framers of the 1982 Constitution have succeeded in decreasing the workload of the Court. Whereas in the 1962-1980 period the Court received an average of 19 cases a year, in the 1983-2000 period that number was reduced to 12 . The proportion of annulments however, has more than doubled from 37 per cent in the first period to 76 per cent in the second. The Court might not be deciding as many cases as it once did, but it has become a more activist court. To be sure many of the findings of unconstitutionality are based on minor technical points. Nevertheless, 76 per cent is an astonishingly high average.

30 A Stone Sweet, Governing with Judges (New York, Oxford University Press, 2000) 50-1.

31 Hürriyet, 15 May 2003. 


\section{Protecting Rights}

Whereas abstract review is a mechanism designed to 'tame the parliament', ${ }^{32}$ concrete review is intended to protect civil liberties. Claims of violation of civil liberties and rights are more likely to arise after a statute has been put into effect. ${ }^{33}$ Turkish law does not allow for individual complaints to reach the Constitutional Court directly, but it does allow the parties to a conflict to raise claims of unconstitutionality of the applied statutes during the course of a trial. If the trial court is convinced that a constitutional question exists, it is required to stop the trial and refer the matter to the Constitutional Court. In such cases the Constitutional Court only decides the constitutional question before it. The original court then tries the facts of the case in light of the Constitutional Court's ruling.

The protection of rights through judicial action in Turkey faces three major structural obstacles. First, as in other countries based on the civil law system, the Constitutional Court only addresses the constitutionality of the law in question not its interpretation by the trial courts. The Constitutional Court only has the power to review the constitutionality of laws and decrees with the force of law, but it does not have the power to review decisions of the other courts. Although Article 153 of the Constitution declares that the decisions of the Constitutional Court 'shall be binding on the legislative, executive, and judicial organs, on the administrative authorities, and on persons and corporate bodies', it does not provide any mechanism for enforcing this provision. A citizen who feels his constitutionally guaranteed rights have been violated by an unconstitutional interpretation of an otherwise constitutional law has no recourse available other than relying on the goodwill of the appellate court. ${ }^{34}$

Secondly, the 1982 Constitution and Turkey's legal codes provide weak foundations for the protection of rights. The leaders of the 1980 coup believed that the political paralysis of the late 1970s and the breakdown of law and order had violated the rights of the state, and that the future political system had to protect these rights. In opening the 1981 Constituent Assembly, General Evren, the leader of the coup, noted:

While trying to enhance and protect human rights and liberties, the state itself has certain rights and obligations as far as its continuity and future is concerned. We do not have the right to put the state into a powerless and inactive position. The state cannot be turned into a helpless institution ... Citizens should know

32 A Stone [Sweet], The Birth of Judicial Politics in France (Oxford, Oxford University Press, 1992) 60.

33 Stone Sweet, above n 30, at 113.

34 This seems to be a common problem for Kelsenian courts. See A Örkény and KL Scheppele, 'Rule of Law: the Complexity of Legality in Hungary' in M Krygier and A Czarnota (eds), The Rule of Law after Communism: Problems and Prospects in East-Central Europe (Brookfield, VT, Ashgate, 1999) 66. 
that freedoms of thought and conscience exist. There are, however, limits to these freedoms; there is also a state founded by individuals that together make up a collectivity. The state in question protects the individuals. This state, too, has a will and sovereignty of its own. Individual freedoms can be protected to the extent that the will and the sovereignty of the state are maintained. If the will and sovereignty of the state are undermined, then the only entity that can safeguard individual freedoms has withered away. ${ }^{35}$

Accordingly, the constitution recognised a long list of civil liberties but it also imposed severe restrictions on the exercise of those rights. Article 14 specified that:

None of the rights and freedoms embodied in the Constitution shall be exercised with the aim of violating the indivisible integrity of the State with its territory and nation, of endangering the existence of the Turkish State and Republic, of destroying fundamental rights and freedoms, of placing the government of the State under the control of an individual or a group of people, or establishing the hegemony of one social class over others, or creating discrimination on the basis of language, race, religion or sect, or of establishing by any other means a system of government based on these concepts and ideas. ${ }^{36}$

Clearly, the protection of individual rights and liberties was secondary to the protection of the rights of the state.

Furthermore, until 2001, the constitution specifically barred the Constitutional Court from reviewing some of the more restrictive laws and regulations that were legislated by the military regime. Although this prohibition was removed in 2001 as part of a European Union harmonisation package, it is not yet clear what effect it might have on the activities of the Court. The constitution also bars the Court from revisiting an issue until 10 years have elapsed from the publication of the Court's original decision in the Official Gazette. This provision is intended to ensure the stability of law, but it has also made it more difficult for the court to quickly correct its 'mistakes'. Given the extent and speed of economic, political and social changes in Turkey over the past two decades, this provision might also have had the unintended consequence of widening the gap between the legal system and the realities faced by the society.

Thirdly, the Turkish Constitutional Court can only accept cases for concrete review on referral from other courts. All trial and appellate courts have the power to refer cases to the Constitutional Court, but some courts seem extremely reluctant to do so. The largest numbers of cases are referred by

35 Quoted in M Heper, The State Tradition in Turkey (Beverly, Eothen Press, 1985) 131.

${ }^{36}$ In 2001, the parliament amended this article to read: 'None of the rights and freedoms embodied in the Constitution shall be exercised with the aim of violating the indivisible integrity of the state with its territory and nation, and endangering the existence of the democratic and secular order of the Turkish Republic based upon human rights'. 
Table 5.2: Cases of Concrete Review Decided by the Turkish Constitutional Court (1983-1998)

\begin{tabular}{lcccc}
\hline Year & New & Annulled & Rejected & Returned* $^{*}$ \\
\hline 1983 & 0 & 0 & 0 & 0 \\
1984 & 6 & 0 & 2 & 0 \\
1985 & 19 & 0 & 4 & 8 \\
1986 & 14 & 0 & 16 & 4 \\
1987 & 22 & 2 & 12 & 4 \\
1988 & 52 & 3 & 7 & 11 \\
1989 & 23 & 3 & 14 & 13 \\
1990 & 27 & 1 & 14 & 7 \\
1991 & 54 & 13 & 18 & 10 \\
1992 & 43 & 3 & 22 & 9 \\
1993 & 33 & 6 & 18 & 10 \\
1994 & 34 & 5 & 12 & 8 \\
1995 & 43 & 15 & 30 & 7 \\
1996 & 61 & 11 & 19 & 6 \\
1997 & 73 & 12 & 17 & 4 \\
1998 & 56 & 17 & 39 & 6 \\
1999 & 39 & 14 & 23 & $\mathbf{2 2 3} * * *$ \\
2000 & 57 & 3 & 279 & $(36.5 \%)$ \\
Total & $656 * *$ & 108 & $(45.7 \%)$ & \\
& & $(\mathbf{1 7 . 7 \% )}$ & & \\
\hline
\end{tabular}

* Returned to the original court.

$* * 610$ cases were decided. Calculations are based on the number of decisions made.

$* *$ Returned (123) or refused to hear (100).

Source: Turkish Republic, State Institute of Statistics, Judicial Statistics (various years).

the administrative courts and concern various administrative and economic reforms. Particularly disturbing is the very small number of cases referred by the State Security Courts. In over 600 decisions by the Constitutional Court, only four have concerned cases referred directly by the SSCs. ${ }^{37}$ In part, this is due to the fact that until 2001 some provisions of the antiterror law were exempt from constitutional review. More important, however, seems to have been the general reluctance of these courts to refer cases for constitutional review.

Between 1984 and 2000, the Constitutional Court received 656 referrals from other courts and delivered decisions in 610 cases. The Court's decisions in these cases are summarised in Table 5.2. The possibility of success in declaring a law unconstitutional through the process of concrete review is low. Of the 610 decisions, only 108 (18 per cent) have struck down a law or regulation; 46 per cent of the claims of unconstitutionality were rejected, while the Court refused to render a decision in 37 per cent of the

37 Cases from trial courts, including SSCs, can be referred to the Constitutional Court either directly by the original court or the appellate court. It is difficult to determine the number of cases from the SSCs reaching the Constitutional Court through the Court of Cassation. 


\section{Hootan Shambayati}

cases, either due to the absence of a substantial constitutional question or for other reasons.

The relatively low success rate of concrete review points to the failure of the Court to emerge as a guardian of individual rights and civil liberties against encroachments by the state. Although the Constitutional Court occasionally has expanded rights, it has not been able to appropriate for itself the role of the protector of civil liberties against encroachments by the state. This is also affirmed by the poor performance of Turkey before the European Court of Human Rights (ECtHR). ${ }^{38}$ This discrepancy points to two very different conceptions of 'rights' by the ECtHR and the Turkish judiciary. The ECtHR emphasises individual rights and civil liberties. The Turkish judiciary, on the other hand, follows an ideology-based paradigm favouring the state. ${ }^{39}$ As a former president of the Constitutional Court put it, 'The state that does not protect itself is not a state'. ${ }^{40} \mathrm{~A}$ similar sentiment was repeated in April 2005 when the sitting president of the Court used the opening of the Court's judicial year to threaten the ruling Justice and Development Party with dissolution if it attempted to lift the ban on headscarf-wearing female students at universities. ${ }^{41}$

\section{Supervision of Political Parties}

When sovereignty is divided between elected and non-elected institutions, the political system is particularly susceptible to anti-systemic movements. As Brumberg notes, these political systems lack a hegemonic ideology and 'can become vulnerable to efforts by competing social forces to radically redefine [their] ideological foundations'. ${ }^{42}$ Unwilling to accommodate new social movements and unable to defeat them at the polls, elements within the system might turn to the courts in an effort to suppress, or at least to undermine, the challengers. As it will be shown below, the Turkish political system, like its Iranian counterpart, has relied very heavily on the courts to suppress political movements that have challenged the hegemony of the ruling elite. ${ }^{43}$

\footnotetext{
38 Many of the cases concerning civil liberties arise from the situation concerning the Kurdish movement. The fight against Kurdish separatism and Islamic fundamentalism has led to numerous allegations of violations of individual rights and civil liberties. In such cases the Turkish courts have often deferred to the security personnel.

39 Z Arslan, 'Conflicting Paradigms: Political Rights in the Turkish Constitutional Court' (2002) 11 Critique: Critical Middle Eastern Studies (Spring) 9.

40 YG Özden, 'Opening Speech by Yekta Güngör Özden, President of the Turkish Constitutional Court', reprinted in YG Özden and E Yildiz (eds), Constitutional Jurisdiction 9: Papers Presented at the International Symposium held at the Thirtieth Anniversary of the Constitutional Court of Turkey, April 25-27, 1992 (Ankara, 1993) 22.

41 Hürriyet, 24 April 2005.

42 D Brumberg, Reinventing Khomeini: the Struggle for Reform in Iran (Chicago, University of Chicago Press, 2001) 34.

${ }^{43}$ See Shambayati, above $\mathrm{n} 9$.
} 
Officially the Turkish state is based on Kemalism, a loosely defined ideology named after the founder of modern Turkey, Mustafa Kemal Ataturk. However, most observers of Turkish politics agree with Zürcher that 'Kemalism never became a coherent, all-embracing ideology, but can best be described as a set of attitudes and opinions, which were never defined in any detail'. ${ }^{44}$ This has allowed the periodic rise of movements that have used both democratic and undemocratic means to challenge the state's definition of Kemalism, particularly with respect to secularism and nationalism.

Since its foundation in 1962, the Court has closed 24 political parties. Of these, six were closed before the 1980 coup and the rest since the return to party politics in 1983 (Table 5.3). The Court has been particularly active since 1991, a date that in many ways signals the return to true civilian politics. ${ }^{45}$ The frequency of party closures in Turkey puts it in a unique category among democratic countries and requires further explanation. In

Table 5.3: Political Party Closures (1983-2003)

\begin{tabular}{lccc}
\hline Year & New cases & Closed & Rejected \\
\hline 1983 & 6 & 1 & 5 \\
1984 & 2 & 0 & 2 \\
1985 & 1 & 0 & 1 \\
1986 & 0 & 0 & 0 \\
1987 & 1 & 0 & 1 \\
1988 & 2 & 0 & 1 \\
1989 & 0 & 0 & 1 \\
1990 & 2 & 0 & 0 \\
1991 & 2 & 2 & 1 \\
1992 & 2 & 1 & 0 \\
1993 & 4 & 3 & 0 \\
1994 & 1 & 3 & 0 \\
1995 & 1 & 1 & 0 \\
1996 & 3 & 1 & 0 \\
1997 & 2 & 2 & 1 \\
1998 & 0 & 1 & 0 \\
1999 & 2 & 1 & 0 \\
2000 & 0 & 0 & 0 \\
2001 & 0 & 1 & 0 \\
2002 & 1 & 0 & 0 \\
2003 & 1 & 1 & 0 \\
Total & 32 & 18 & 13 \\
\hline
\end{tabular}

Source: Turkish Republic, State Institute of Statistics, Judicial Statistics (various years) and Anayasa Mahkemesi.

${ }^{44}$ E J Zürcher, Turkey: A Modern History (London, IB Tauris, 1994) 189.

45 Although technically Turkey had returned to civilian rule in 1983, the leader of the military coup had remained as the President of the Republic until 1990. Furthermore, until the referendum of 1987 the constitution barred the pre-coup political leaders from active participation in politics. 
fact, the closure of political parties in Western democracies is so rare that in 1988 Alexander von Brüneck could argue, 'This function of constitutional courts has in recent times lost much of its significance'. ${ }^{46}$ This, of course, has somewhat changed in recent years. Nevertheless, party closures are extremely rare in established democracies. ${ }^{47}$

One factor that might explain the difference between Turkey and other Western democracies is the low political cost of party closures for the government in power and for the political system as a whole. As I will argue in this section, both the Turkish Constitutional Court and political institutions have devised a number of mechanisms to reduce the potential political cost of party closures.

First, unlike in either Germany or Spain, the elected government and parliament have no role in closure of political parties. Under Article 69 of the Constitution the power to bring suits for the closure of political parties or for the issuance of warnings to them is given to the Chief Public Prosecutor of the Court of Cassation (Yargitay) who acts as the Chief Public Prosecutor of the Republic in cases before the Constitutional Court. The Chief Public Prosecutor is a professional prosecutor appointed by the President of the Republic from a list of nominees prepared by other prosecutors. It is not possible to hold him/her democratically accountable. Nor is it possible to hold the members of the Constitutional Court or those who have appointed them accountable.

Furthermore, prosecutors have little fear of failure when asking for the closure of political parties. Since 1989, the Constitutional Court has acted on 20 petitions for party closures. It has granted the petition on 17 occasions (Table 5.3). When the prosecutor asks for the closure of a political party

46 A von Brüneck, 'Constitutional Review and Legislation in Western Democracies' in C Landfried (ed), Constitutional Review and Legislation: an International Comparison (BadenBaden, Nomos, 1988) 242-3.

47 The Western country most often cited for the closure of political parties is Germany. Article 21, para 2 of the German Constitution reads, 'Parties which, by reason of their aims or the behaviour of their adherents, seek to impair or abolish the free democratic basic order or to endanger the existence of the Federal Republic of Germany are unconstitutional. The Federal Constitutional Court decides on the question of unconstitutionality'. Using this article the German Constitutional Court closed the neo-Nazi Socialist Reich Party (SRP) in 1952 and the Communist Party in 1956. Neither of these parties was a major political force at the time of its closure, although the SRP occupied two seats in the federal parliament, and both parties reappeared in later years under different names and with more moderate programmes. Since 1956, the German courts have not closed any political parties. In 2003, the court rejected a joint petition by the government and the two houses of parliament to close the neo-Nazi National Democratic Party (Nationaldemokratische Partei Deutschlands (NPD)). The other example of party closure in a Western democracy is the Spanish Constitutional Court's decision to outlaw the Basque party Batasuna in 2003. On the closure of political parties in Germany, see John E Finn, Constitutions in Crisis: Political Violence and the Rule of Law (Oxford: Oxford University Press, 1991) 191-3; DP Kommers. The Constitutional Jurisprudence of the Federal Republic of Germany (Durham, Duke University Press, 1989). For the Spanish case, see L Turano, 'Spain: Banning Political Parties as a Response to Terrorism' (2003) 1:4 International Journal of Constitutional Law 730-40. 
there is an 85 per cent chance that his request will be granted (Table 5.3). The prosecutor's success rate is even higher when he asks the Constitutional Court to issue a warning to political parties. In such cases the prosecutor can expect a favourable outcome for 95 per cent of his petitions.

Given the frequency of party closures, it is not surprising that both the parliament and the Court have taken a number of steps to reduce further the potential costs of closures. For example, in its original version, Article 84 of the Constitution read:

The membership of a deputy, whose acts and statements are cited in a judgment of the Constitutional Court as having caused the dissolution of a political party and that of other deputies who belonged to the party on the date when the action for dissolution was brought, shall end when the Presidency of the Turkish Grand National Assembly is notified of the dissolution order. (emphasis added)

This meant that when a political party was closed all the deputies from that party in the parliament lost their seats, threatening the parliament with automatic dissolution due to lack of quorum. In 1995, the Constitutional Court closed the pro-Kurdish Democrat Party (DEP). At the time, DEP had a small number of deputies in the parliament. After much wrangling DEP deputies eventually lost their parliamentary immunities and were put on trial. ${ }^{48}$ Some, including the much-celebrated Layla Zana, were convicted and imprisoned. ${ }^{49}$

Although the number of DEP deputies was not large enough to threaten the continuation of the parliament, the Constitutional Court's willingness to close a party with representation in the parliament raised the possibility that the closure of political parties might potentially threaten the parliamentary term. Accordingly, in July 1995 the parliament amended the relevant clause of Article 84 to limit the loss of membership to only those deputies 'whose acts and statements are cited in a judgment of the Constitutional Court as having caused the dissolution of a political party'.

The wisdom of this change became apparent when the Court closed the pro-Islamist Welfare Party and its replacement the Virtue Party in January 1998 and June 2001, respectively. At the time of its closure Welfare was the largest party in parliament and in fact until June 1997, when it was forced to resign under pressure from the military, it had been the party in power. Virtue, which had replaced Welfare after the latter's closure, was the main opposition party in 2001. Under the amended version of Article 84 , the Constitutional Court chose to hold a very small number of deputies

48 NF Watts, 'Allies and Enemies: Pro-Kurdish Parties in Turkish Politics, 1990-94' (1999) 31 International Journal of Middle East Studies (November) 631.

${ }_{49}$ In 2001, ECtHR ordered new trials for the jailed deputies. Eventually the Turkish parliament amended the law to allow new trials in response to ECtHR rulings and the four deputies still in jail were retried and eventually released in 2004. 
responsible for the closure of the two parties, preventing the dissolution of the parliament.

The parliament and the Court have also taken further steps to minimise the cost of party closures. A common phenomenon in Turkish politics is the appearance of what may be called reserve parties. When a political party faces closure some of its members resign to form a new party and as the date for closure gets closer elected officials belonging to the threatened party move to the new party. This strategy was made possible by the 1995 constitutional amendments and the Court's deliberate interpretations. In its original version Article 69 of the Constitution read:

The founding members and administrators at every level of a political party which has been permanently dissolved shall not become founding members, administrators, or comptrollers of a new political party; nor shall any new political party be founded, the majority of whose members are former members of a political party previously dissolved.

This clause, however, proved unenforceable and was amended by the parliament, thus allowing the members of the closed party to join a new party.

The strategy of setting up reserve parties has been particularly popular with pro-Kurdish and Pro-Islamist political parties that have a social base. The main pro-Kurdish political party, the Democratic People's Party (Demokratik Halk Partisi, better known by its Turkish acronym DEHAP), for example, which controls a number of municipalities in the Kurdish populated regions of south-eastern Turkey, was set up when it became clear that the party's predecessor, the People's Democratic Party (Halkin Demokrasi Partisi or HADEP) was on the verge of closure. HADEP itself had risen from the ashes of three earlier closed pro-Kurdish parties. On the same day that HADEP was closed (13 March 2003) the Chief Public Prosecutor filed a petition for the closure of DEHAP. Similarly, the Justice and Development Party, which is the ruling party at present (November 2005) is a successor to the closed Virtue Party (closed by the Court in 2001), which was a successor to the closed Welfare Party (closed by the Court in 1998), which was a successor to the closed National Salvation Party (banned after the 1980 coup), which was a successor to the closed National Order party (closed by the Court in 1971).

In October 2001, under pressure from the European Union, the parliament once again amended the constitution to tighten conditions under which parties can be closed. According to Article 68, political parties can still be closed if their:

statutes and programmes, as well as the activities ... [are] in conflict with the independence of the state, its indivisible integrity with its territory and nation, human rights, the principles of equality and rule of law, sovereignty of the nation, the principles of the democratic and secular republic; they shall not aim to protect or establish class or group dictatorship or dictatorship of any kind, nor shall they incite citizens to crime. 
According to Article 69, 'A political party shall be deemed to become the centre of such actions only when such actions are carried out intensively by the members of that party' (emphasis added).

Furthermore, under the new arrangement, the closure of a political party would require a three-fifths ( 7 out of 11 ) vote. Also, the Constitutional Court now has the option of imposing monetary fines and/or to deny state aid to the offending party. What effect these changes will have on party closures is not clear. Although the overall number of party closures might decline, as the closure of HADEP in 2003 shows, it is unlikely that it will change the Court's attitude toward pro-Kurdish, pro-Islamist, or other ideologically motivated and/or ethnically organised political parties.

Although the Court vehemently opposed these changes and issued a public statement warning the government that the changes would leave Turkey defenceless against separatist (pro-Kurdish) and reactionary (Islamist) movements, these changes should not be viewed as an attack on the Court's powers. ${ }^{50}$ The Court still has the right to close political parties. Furthermore, the members of the Court themselves have been complaining about the high number of party closures in Turkey. ${ }^{51}$

In short, The Turkish Constitutional Court is an activist court that has not shied away from engaging in political controversies. The record of the Court clearly indicates its willingness to 'tame the parliament'. At the same time, the Court has been more reluctant in acting against the state. At best, its record has been modest in 'taming the state'. If, as Saïd Arjomand suggests, the Iranian Council of Guardians is the guardian of shari' $a$ and the Egyptian Supreme Constitutional Council is the guardian of the constitution, ${ }^{52}$ the Turkish Constitutional Court, to quote its former president, is 'the guardian of the regime'. ${ }^{3}$

\section{DIVISION OF SOVEREIGNTY AND THE STATE STRUCTURE IN IRAN}

A comparison with Iran is, however, much more illuminating than one with Egypt. The political system of the Islamic Republic of Iran, as Daniel Brumberg has noted, is an example of 'dissonant institutionalisation'. As Brumberg notes, 'dissonant institutionalization occurs when competing images of political community and the symbolic systems legitimating them

\footnotetext{
50 'Anayasal Muhtira' (Constitutional Memorandum), Milliyet, 23 January 2001; Turkish Daily News, 24 January 2001.

51 40. Kurulus, Günü Töreni Açilis Konusmasi (Speech of the President of the Constitutional Court on the Occasion of the Beginning of the Court's 40th Term), 25 April 2002, available at www.anayasa.gov.tr/ydonum/k40.htm (visited 26 March 2004). See also, Turkish Daily News, 26 April 2002.

52 SA Arjomand, 'Islam and Constitutionalism: the Significance and Peculiarities of Twentieth-Century Iran', ch 2 in this volume.

53 YG Özden, 'Opening Speech by Yekta Gungor Ozden, President of the Turkish Constitutional Court' (Ankara: The Constitutional Court of Turkey, 1993) at 9.
} 


\section{Hootan Shambayati}

are reproduced in the formal and informal institutions of state and society' ${ }^{54}$ The 1979 Iranian Constitution officially recognises the power of the people and the role of elections in legitimising the state. At the same time, it declares that 'absolute sovereignty belongs to God' (Article 56) and subjects elected institutions such as the presidency and the parliament to control by the Supreme Leader of the Revolution (vali-ye faqih), an undemocratically and indirectly selected official representing the will of God. ${ }^{55}$ This institutionalisation of competing ideologies has produced a political structure composed of contradictory elements. The system's democratic elements encourage change, while its authoritarian features try to limit the impact of that change. ${ }^{56}$

The Islamic Republic has tried to manage the resulting tensions through a number of extra-political institutions. One of the most important of these institutions is the controversial Council of Guardians. ${ }^{57}$ According to the Constitution, the Council was established 'to safeguard the Islamic ordinances and the Constitution, [and] to examine the compatibility of the legislations passed by the Islamic Consultative Assembly with Islam' (Article 91). In addition, the Council has the responsibility to supervise elections for the Assembly of Experts, the presidency and the parliament (Article 99).

The Council of Guardians is a combination upper house of the parliament and constitutional court. Two aspects of the Council's powers, however, distinguish it from conventional upper houses found in other countries. First, the Council does not have the power to initiate legislation on its own. Similarly to a constitutional court, it can only review legislation adopted by the parliament (majlis). Secondly, the Council has the exclusive power of constitutional review. What distinguishes the Council from a proper constitutional court, as the term is generally understood in other political systems, is that legislation adopted by the majlis cannot become law without the consent of the Council that it meets both the requirements of Islamic law and the Constitution.

It is also clear that the Constitution sees the Council of Guardians as superior to the parliament. Article 93 of the Constitution specifically states

${ }^{54}$ Brumberg, above $\mathrm{n} 42$, at 33-4.

55 On the political structure of the Islamic Republic of Iran, see inter alia W Buchta, Who Rules Iran? The Structure of Power in the Islamic Republic (Washington, DC, Washington Institute for Near East Policy, 2000); HE Chehabi, 'The Political Regime of the Islamic Republic of Iran in Comparative Perspective' (2001) Government and Opposition 36; M Kamrava and H Hassan-Yari, 'Suspended Equilibrium in Iran's Political System' (2004) The Muslim World (October) 94.

56 Brumberg, above $\mathrm{n} 42$, at 5 .

57 SA Arjomand, 'Civil Society and the Rule of Law in the Constitutional Politics of Iran under Khatami' (2000) 67(2) Social Research (Summer) 283-301; A Gheisssari and V Nasr, 'Iran's Democracy Debate' (2004) 11(2) Middle East Policy (Summer) 94-105; Mehrangiz Kar, 'The Deadlock in Iran: Constitutional Constraints' (2003) 14(1) Journal of Democracy (January) 132-36; AW Samii, 'Iran's Guardian Council as an Obstacle to Democracy' (2001) Middle East Journal (Autumn) 55. 
that 'The Islamic Consultative Assembly does not hold any legal status if there is no Guardian Council in existence, except for the purpose of approving the credentials of its members and the election of the six jurists on the Guardian Council'. Furthermore, the members of the Council can take part in parliamentary debates while the reverse is not true for the members of the parliament.

The Council is composed of six clerics and six non-clerical jurists. The first group are appointed directly by the Supreme Leader while the parliament appoints the non-clerical jurists. The parliament's role in influencing the composition of the Council is severely limited by the constitutional requirement that the non-clerical jurists be nominated by the Head of the Judiciary, himself appointed by and responsible to the Supreme Leader. All 12 members determine compatibility of legislation with the Constitution. However, only the clerics on the Council can determine compatibility with Islamic law. Furthermore, decisions of the Council concerning conformity with Islamic law require the support of only a simple majority of the clerical members while those concerning constitutional issues require the affirmative vote of three-fourths of the entire body. In other words, although the lay jurists on the Council have no role in determining conformity with Islamic law, the support of at least three of the clerical members is needed in determining constitutionality. Members of the Council serve for renewable six-year terms (Articles 91-99).

One consequence of the structure of the Council of Guardians and its role in the legislative process has been the institutionalisation of a high level of tension between the parliament/presidency and the Council of Guardians. These tensions reached a high point during the presidency of Mohammad Khatami (1997-2005), when the Council rejected 111 out of his 297 legislative proposals, including some concerning the powers of the Guardian Council itself. ${ }^{58}$ Similarly, the Council used its supervisory powers to disqualify many reformist candidates from standing in parliamentary and presidential elections. At the same time, the courts and the judiciary joined the battle between the reformers and more conservative elements by banning numerous reformist newspapers and imprisoning reformist intellectuals and activists.

It would be a mistake, however, to contribute the tensions inherent in Iran's political system to ideological differences between the reformers and the conservatives. Reforms, of course, test the boundaries of the constitutional system. However, tensions between the parliament and the Guardian Council were not unique to Khatami's tenure and have their roots in the institutional structure of the Islamic Republic. In fact, these tensions first appeared under Khomeini himself and eventually led him to decree into

${ }^{58}$ L Secor, 'Fugitives: Young Iranians Confront the Collapse of the Reform Movement', New Yorker, 21 November 2005, 64. 


\section{0}

existence the Expediency Council charged with the task of settling the differences between the parliament and the Guardian Council.

The Supreme Leader appoints all members of the Expediency Council (majma'-e tashkhis-e maslahat) and the Council reports to him directly. ${ }^{59}$ The heads of the three branches of government and the clerical members, but not the lay members, of the Guardian Council are members of the Council. The Expediency Council also includes a number of other religious and political personalities appointed by the Supreme Leader. Furthermore, depending on the issues on the agenda, other individuals can be invited to take part in the deliberations of the Council.

The Expediency Council has two primary functions. First, it is to resolve the differences between the Majlis and the Council of Guardians. Secondly, it is to act as an advisory Council to the Supreme Leader. The Council establishes the overall policy orientation of the Islamic Republic that the other organs are required to follow. In this regard, the Expediency Council is somewhat similar to the Turkish National Security Council discussed above, which also serves as a forum for joint policy-making by the guardians and elected officials. Both institutions are recognition of the fact that the political system embodies a high level of tension between elected and unelected institutions that, if left unchecked, could paralyse the political system.

Though tempting, it would be wrong to attribute reliance on extrapolitical institutions to the peculiarities of the Iranian system or the needs of theocracy. As I have shown, reliance on extra-political institutions is characteristic of the systems where elected officials share power with unelected guardians, including the political system of secular Turkey.

\section{CONCLUSIONS}

The challenge for many developing countries is how to accept the ideals of popular sovereignty and universal suffrage as the basic organising principles of the polity while designing an institutional framework that would effectively deny the franchise to those segments of the society who oppose the project of the state elite. An earlier generation of constitutional framers could overcome this problem by formally denying the vote to certain groups in society. For designers of modern constitutions, however, there is no escape from the need to minimise formal limits on the right to participate in the political life of the community. This is not only true in democracies like Turkey, where the modern understanding of the term by definition includes universal suffrage, but also in countries like Iran, where public support is accepted as one of the main legitimating factors by the regime.

\footnotetext{
59 See www.iranonline.com/iran/iran-info/Government/Expediency.html
} 
The consequence has been the division of sovereignty between elected institutions and unelected guardians.

As I have shown in this chapter, despite their different regime types and opposing ideologies, in both Turkey and Iran elected institutions function side by side with guardians who see their own role as safeguarding the state project against powerful social interests, even when those interests form a majority in the polity. In Iran, the Supreme Leader sees himself as the guardian of the Islamic nature of the system, while the Turkish military sees itself as the defender of secularism. The heavy reliance on extra-political institutions such as Iran's Guardian Council and Turkey's Constitutional Court that characterises both political systems, hence, is not a function of theocracy or secularism. Rather, as I have tried to show in this chapter, it is a consequence of the division of sovereignty between elected and unelected institutions and is designed to limit the powers of elected institutions without undermining the above-politics posture of the guardians. 